УДК 339.56

JEL P33, L6, F14, O14

DOI: $10.17213 / 2312-6469-2020-4-165-172$

\title{
MODELING OF MULTI-CRITERIA EXPERT EVALUATION OF INNOVATIVE PROSPECTS OF THE INFORMATION ECONOMY SECTORS
}

\author{
(C) Alovsat G. Aliyev 2020 \\ Institute of Information Technology of Azerbaijan National Academy \\ of Sciences, Baku, Azerbaijan
}

The article is devoted to modeling of multi-criterion expert evaluation processes of innovative perspectives of information economy sectors and analysis of its experimental results. It was shown that in modern times, ICT and high-tech production areas of science have become the main sector of the world economy. In this sense, a comprehensive assessment of its perspektiv directions is of particular importance for the effective structuring of the emerging economy. The article explains the goals of creating a intellectual society and economy. Problems of information economy have been identified. The degree of research and development of information economy problems has been analyzed in detail. The features of regional and sectoral approach to the evaluation of information economy were studied. New areas of information, knowledge and technological economy have been identified. Evaluation of innovative perspectives of information economy sectors is modeled on the basis of a multicriterion expert assessment method. Recommendations were made based on the results obtained.

Keywords: information economy, ICT, technological economy, innovative perspectives, regional and sectoral approach, innovative development, multi-criteria expert assessment.

\section{Introduction}

In the modern era, the production areas of ICT and high-tech products of science have become the main sector of the world economy in line with the challenges of the 4.0 Industrial revolution. The process of replacing the industrial economy with the information economy of the post-industrial period began [1]. The coronavirus pandemic, which has escalated since the beginning of 2020, proved that the importance of these processes is very high. Therefore, a comprehensive assessment of its perspective directions is of particular importance in order to implement effective structuring and other problems of the emerging economy.

\section{The goals of creating an intellectual society and economy}

Information economy manifests itself as the next stage of economic development. Technological development and innovations are the long-term 
driving force of economic growth. Information resources and knowledge become a major development factor of society. Economic growth in the information economy is ensured through the use of information sources and resources. Information resources create additional opportunities for more efficient use of other production factors. Taking this into account, the development of new knowledge-based society, as well as scientific innovations in the field of economy, science-education and entrepreneurship structures, information bases on innovations in the development concept documents adopted at the state level in Azerbaijan [2-4] has been set as the main goals before the state and society. The process of creating automated knowledge in the development of newly formed economic areas, internet control in all areas, remote control technologies, artificial intelligence and robotics, etc. such innovative technologies will be widely applied. Management processes include the development of advanced high technologies (bio, nano, information, communication, industry, finance, etc.) will be carried out in accordance with the requirements.

\section{Problems of information economy}

Against the backdrop of scientific and technological problems, there was a serious need to analyze and assess the level of the developing information economy. There are some methodological defects and application difficulties of the system of indicators developed by international organizations in order to realize quantitative and qualitative identification of high technologies, including the level of application of ICT in various fields. Therefore, to assess the level of development of information economy sectors, it is also necessary to develop a new system of improved indicators and evaluation indexes at different levels [5]. The development of the methodology and methods of their formation and recommendations for the elimination of existing problems in this field is one of the topical issues.

The technical and technological characteristics of the activities of the ICT sector, which is the basis of the information economy, should be investigated and the areas of development identified. The sectoral-regional problems of the development of economic activity on the basis of ICT should be resolved. The formation characteristics of the national innovation system should be analyzed and development trends should be determined in the new conditions [6]. In this direction, the establishment of the main driving innovative structures of the economy, the organization and management of its activities should be improved. The peculiarities of buying and selling, application of payment technologies and systems on the basis of modern ICT should be adapted to the new economic requirements. The newly formed information economy should be formalized in accordance with the requirements of the green economy, the balance of the ecological-economic balance, a stable, sustainable course of innovative economic development, increasing the level of inclusiveness, taking into account the 4.0 industrial revolutionary components. 


\section{The degree of research and development of information economy problems}

In connection with the study of the issues considered, it should be noted that the scientific-technological basis of the stages of development of society and economy, the gradual transition to each other, the signs of the formation of the information economy of the new era, technologies, features have been subject to research by many foreign, including Russian, as well as domestic scientists [7-9]. In order to develop the scientific, technical and technological aspects of the ICT sector, which is the main field of information economy, a lot of research works have been carried out in the fundamental scientific-theoretical and applied nature [10]. At the same time, with the expansion of new economic activity areas, serious research work was carried out on the organization of more advanced activities in the ICT base of traditional economic areas. In this direction, various researchers have tried to explore different aspects of the new information economy, which has recently been analyzed in scientific literature, as the stage of development of the post-industrial economy [11].

In addition, innovation, innovative processes, innovative structures, the formation of National Innovation System and some aspects related to them are studied by many authors. Thus, the commercialization of innovations, the modeling of innovation processes, the transfer of innovative technologies, the efficiency factors of innovations and their implications are reflected in the works of many researchers $[12,13]$.

Despite certain work done in this area, the problems of information economy formation and its theoretical aspects have not been sufficiently studied and researched. The categorical apparatus of the information economy is still at the stage of development. The boundaries between many concepts are not completely clarified. In connection with the development and implementation of concepts for the formation and development of information society, issues related to the detailed study, realization of the essence and content of information economy, determination of its structure and comparative analysis of scientific and theoretical approaches in the relevant fields are of particular urgency at the present time.

\section{The goals and objectives of the study of information economy}

The purpose of research in this area is to propose conceptual solutions based on the analysis of the problems of modern and strategic formation of a new type of information economy, which is the economic basis for building an information society, as well as to improve the current state of the information economy. development of models, methods, algorithms and mechanisms.

\section{Features of the regional and sectoral approach to the assessment of the information economy}

The analysis shows that there are different approaches, indicators, methodologies, indices and so on in assessing the level of the information economy. The base groups to be selected for comparison do not fully meet the 
needs and regional characteristics. Therefore, in the systematic analysis of the formation of the information economy at the international and national levels, it is proposed to accept the functional stages of economic development as: 1) agrarian, 2) industry, 3) information, 4) knowledge, 5) intellectual. This division should be taken into account during the analysis and evaluation.

In addition, the selected group of world countries for comparative analyses and evaluations will include: developing countries (G7, G10, G20), the countries of the former Union of Soviet Socialist Republics, Commonwealth of Independent States (CIS) countries, countries in the nearby regions, developing countries with similar conditions. From this point of view, the group of countries selected for comparison has been concretely established such countries as USA, UK, Germany, France, Italy, Canada, Japan, China, Russia, India, Korea, Turkey, Switzerland, Sweden, Austria, Iran, Malaysia, Singapore, Israel, Ireland, Pakistan, Hungary, Bulgaria, Kazakhstan, Ukraine, Azerbaijan, Belarus, Uzbekistan, Georgia, Armenia. At the same time, the current economic and administrative division of Azerbaijan was adopted.

In order to carry out economic analysis in a more compact area, it is possible to classify the subsections of the information economy. With this in mind, the sectoral classification of the information economy, taking into account a wider range of digital sub-sectors, can also be formulated as follows: Internet; Software Engineering and automation technologies; digital content; IT-service, telecommunications; computer and electronic industry; creative technologies and digital media; robotics and artificial intelligence; military industry; aerospace and aviation industry; Management services; Bio, nano and high technologies; business and industrial services, pharmaceutical and E-medicine industry; environment and ecology; optical industry; transport and communication; energy sector; chemicals and petrochemicals, Research, Experience-Design Works; scientific technological service areas; education; Media sector; Big data; Internet of Things (IoT); cyber-physical systems; Smart technologies.

It should also be noted that during the analysis of this division, we should not forget about the traditional sectors of economy. Therefore, agriculture, industry, metallurgy, transport, construction, oil and gas, energy, natural resources, etc. although they belong to traditional fields, Information and knowledge can also be included in the sectoral classification of the economy. In addition, it is necessary to include science-intensive subsections of traditional economic sectors and emerging economic sectors (table 1) in the analysis process.

Information, knowledge, technology, innovation capacity sub-sectors of traditional economy [14]: 1) Information and communication technologies and tools in management; 2) Production and service processes technologies; 3) Agrarian techniques and technologies; 4) Marketing-sales, logistics, service technologies. 
New fields of information, knowledge and technological economy

\begin{tabular}{|l|l|}
\hline ICT economics & Bioeconomics \\
\hline Space economy & Nanoeconomy \\
\hline Medical economics & Language economics \\
\hline Education economics & Science economics \\
\hline Cultural economy & Creative - Art economy \\
\hline Smart technology economy & Ecological (green) economy \\
\hline Sports economics & Content-data economics \\
\hline Alternative energy economy & Diaspora economy \\
\hline Theological (religious) economy & Patent (license) economy \\
\hline Behavioral (psychological) economy & Digital economy \\
\hline
\end{tabular}

In the process of assessing the innovative prospects of the information economy sectors, it is proposed to use more and more critical expert assessments. This is also justified by the fact that the existing sphere has not been provided with sufficient information resources and information as a new direction.

It is known that in the context of complex work and uncertainty, the solution of the problem of management decision-making (MDM) has become necessary in many processes, organizations, management levels and enterprises. In such cases, methods and tools for multi-criteria analysis of MDM are usually used. Multi-criteria analysis occurs in the solution of many economic, social, environmental, technical, and social processes, both individually and collectively. Its essence and idea is to choose the most advantageous and useful set of concrete possible alternatives and present it to the decision-maker. The main feature of multi-criteria analysis is that the samples are based on more usefulness and advantages. There must be both quantitative and qualitative criteria. Different methods of multi-criteria analysis allow to obtain results in accordance with different scenarios of MDM.

\section{Evaluation of innovative perspectives of information economy sectors}

The modeling of the algorithmic stages of the proposed expert assessment for the evaluation of innovative perspectives of the information economy is as follows $[15,16]$.

Step I. Selection of experts and determination of weight ratios. N number of specialists-experts with some work experience in this field, scientificpractical, innovation and achievements in the field of education are involved in the virtual survey. The main purpose of the survey is to identify preliminary experts. Each person is evaluated on a scale $(0,10)$. The admission of the first $\mathrm{M}$ specialists with the highest scores as experts is discussed and confirmed, or the process is repeated in another format.

A group of experts (number $\mathrm{N}$ ) can act on 2 scenarios.

a) Experts have equal weight. 
b) Experts evaluate each other on a scale of $(0,10)$ and the results are normalized (divided by the number of initial experts) by weighing each expert in relation to each other $(1,10)$.

Thus, in the first case, the weights of all experts are taken as 1 . In the second case, the weights are in the coefficients $(1,10)$ and, as a result, get the same $1 \leq k_{1}, k_{2}, \ldots, k_{n} \leq 10$ values. For the simplicity of the calculation method, it can be assumed that the weight coefficients are equal to 1 .

Step II. Indicators for assessing the prospects of sub-sectors. At this stage, the assessment indicators are also determined by experts. The following indicators are proposed for the evaluation of innovative perspectives of the sub-sectors of the information economy:

1) the level of innovation of the sub- sector;

2) potential level of development of the sub-sector;

3 ) the level of opportunity to create new jobs in the sub-sector;

4) the level of social usefulness of the sub-sector;

5 ) the level of influence of the sub-sector on the development of other areas;

6) present infrastructure level of the sub-sector;

7) necessary personnel level of the sub-sector;

8) export level of the sub-sector;

9) green and inclusiveness level of the lower area;

10) the level of competitiveness of the sub-sector.

Step III. Evaluation of the prospects of sub-fields. Average expert assessments on all indicators are calculated based on the evaluations characterizing perspective direction (sub-sector) of each expert.

The estimates will show that the sub-fields are consistently arranged according to their significance, like the case of increasing ranges.

Step IV. Processing of expert evaluations. The table of preliminary expert assessments on innovation assessment of perspective sub-sectors of the information economy is drawn up. Based on this table, the perspective subsectors of the information economy are also determined.

\section{Conclusion}

The sub-sectors of the information economy have been identified by experts as the most promising of the many possible options. Clustering was carried out on the basis of expert assessments of 100 sub-areas included in the analysis and evaluation process on the relevant indicators. The results obtained were transferred to a relatively small number of aggregation groups and presented in the form of the following 22 sub-areas and and relevant perspective assessments:

- Automated military industry - 13,8;

- Big data, Cloud and Content-data economy - 36,2;

- Bio, nano and high technologies - 33,1;

- Blockchain and e-commerce - 42,8; 
- Ecology (green) and inclusive economy - 34,7;

- Science and education economics - 72,9;

- Areas of service with scientific and technology capacity - 32,6;

- E-culture economy - 18,6;

- E-medical economy - 36,9;

- Automated marketing in traditional economy - sales, logistics, service technologies - 71,6;

- Automated agricultural machinery and technologies in traditional industries $-23,7$;

- Technologies of automated production and service processes in the fields of traditional economy $-55,8$;

- ICT and tools in the management of traditional sectors of the economy 87,3

- ICT, Internet and telecommunications sphere - 92,5;

- İoT and Cyber-physical systems - 67,8;

- Computing and electronic industry - 35,4;

- Space informatics and drone technology - 23,7;

- Mobile systems - 35,5;

- Autonomous transport - 24,3;

- Software engineering and automation technologies - 76,5;

- Digital media - 33,7;

- Robotics, smart technologies and artificial intelligence - 68,6.

Thus, as a result of the processing of expert evaluations, innovative perspectives of the newest sub-sectors of the information economy were adopted. Taking those factors into account will create a scientific and technological basis for the perspective structuring of the regional economy and can lead to the formation of new sources for economic growth.

\section{References}

1. Alguliyev R.M., Aliyev A.G., Abbasova V.A. The study of formation characteristics and development tendencies of international information and knowledge economy// Review of knowledge economy. 2017. Vol. 4. No 1. P. 7-14.

2. Development Concept "Azerbaijan - 2020: Outlook for the Future". Baku, 2012. P. 34. https://president.az/files/future_en.pdf.

3. National Strategy for the development of Information Society in the Republic of Azerbaijan for 2014-2020. Baku, 2014. https://president.az/articles/11312.

4. Strategic Roadmap for the Development of Telecommunications and Information Technologies. Baku, 2016. http://www.mincom.gov.az; http://www.president.az.

5. Алиев А.Г. Эволюция экономической теории формирования секторов информационной экономики. XXI Международная научная конференция «Проблемы управления и моделирования в сложных системах» (ИПУСС Российской Академии Наук). Труды XXI Международной конференции (3-6 сентября 2019 г. Самара, Россия): в 2-х т., 2019. T. 2. С. 349-353. 
6. Aliyev A.G. Study of scientific-theoretical and methodological foundations of the formation of information economy sectors // Problems of İnformation Society. 2018. № 2. P. 84-96.

7. Сударкина Е.С. Анализ структуры российской экономики на современном этапе и перспективы развития // Экономика и управление. 2016. № 1. С. 57-58.

8. Farshad F.M., Nasser E. et al. Appropriate theoretical framework for understanding and analyzing economic issues in knowledge-based economy // Journal of the knowledge economy. 2017. Vol. 8. Issue 3. P. 957-976.

9. Alguliyev R.M., Aliyev A.G. The development of indicators and indices system characterizing information and knowledge economy // 2017 IEEE 11th International conference on application of information and communication technologies (AICT-2017). 20-22 September 2017, Moscow, Russia. P. 217-222.

10. Макаров В.В., Блатова Т.А. Информационно-коммуникационные технологии как индикатор развития экономики знаний // Российский гуманитарный журнал. 2014. № 4. Том 3. C. 275- 281.

11. Semenyuk E. P., Kotlyarevskyy Ya.V., Kniaziev S.I. et al. Information economy: the formation of special-purpose categorical framework // Science and innovation. 2017. Vol. 13. Issue 3. P. 5-19.

12. Dziallas M., Blind K. Innovation indicators throughout the innovation process: An extensive literature analysis // Journal of technovation. 2019. Vol. 80-81. P. 3-29.

13. Aliyev A.G., Shahverdiyeva R.O. Structural analysis of the transformation processes of scientific and technical ideas and knowledge into innovations in technoparks //International Journal of Engineering and Manufacturing (IJEM). 2017. № 2. P. 1-10.

14. Aliyev A.G. Methodological features of information economy assessment // Azerbaijan State University of Economics (UNEC). Scientific News. 2017. Volume 5, July-September. P. $74-91$.

15. Мамедова М.Г., Джабраилова 3.Г. Нечеткая многокритериальная модель поддержки принятия решений в задачах управления персоналом // Проблемы информационных технологий. 2012. № 2. С. 37-46.

16. Соколова М.Л., Градусов Д.А., Чернов В.Г. Моделирование и исследование метода многокритериального альтернативного выбора ELECTRE в условиях неопределенности экспертных оценок // Динамика сложных систем - XXI век. 2016. T. 10. № 4. С. 82-90.

Поступила в редакиию 25.07.2020

Алиев Аловсат Гараджа - кандидат экономических наук, доцент, заведующий отделом Института Информационных Технологий, Национальная Академия Наук Азербайджана, г. Баку, Азербайджан.

Aliyev Alovsat Garaja - Ph.D., associate professor, Head of the Department of the Institute of Information Technologies of ANAS, Baku, Azerbaijan.

Азербайджан, г. Баку, ул. Суверенитета, 10

10, Suvereniteta str., Baku, Azerbaijan

e-mail: alovsat_qaraca@mail.ru 